\title{
EVALUASI PROGRAM KELURAHAN TANGGUH BENCANA DI KOTA PADANG
}

\author{
Rimala Salwa \\ Jurusan Ilmu Administrasi Negara, Fakultas Ilmu Sosial, Universitas Negeri Padang \\ Email: rimala.salwa@gmail.com \\ Zikri Alhadi, S.IP, MA \\ Jurusan Ilmu Administrasi Negara, Fakultas Ilmu Sosial, Universitas Negeri Padang \\ Email : $\underline{\text { ianunpzikri@yahoo.co.id }}$
}

\begin{abstract}
The purpose of this study was to evaluate or assess whether the program of disaster resistance subdistrict has run optimally and whether the program was feasible to continue. This research was a qualitative research with descriptive method. The selection of informants was done through purposive sampling. Data were collected through interviews and documentation studies; then the data were analysied through presenting data, data reduction, and verification of data. The instruments used in this study were the researchers themselves, interview guides in the form of granules of questions that had been prepared, while to support documentation related to research eating data collection tools that I use are cameras, mobile phones, and recording devices that are useful for recording interviews with informants so that it can facilitate the compilation of data and the validity tested of this data used source triangulation technique, and than the data were analyzed with qualitative data technique. So that the results of this study can be concluded that the program that had been did in Lolong Belanti Village of Padang City had not optimally and the objectives of the program had not been achieved as a whole.
\end{abstract}

Keywords : evaluation, program, Disaster Resistance Subdistrict

\section{Pendahuluan}

Indonesia adalah negara yang rawan akan bencana. Bencana tidak bisa lepas dari faktor alam atau pun dari faktor kegiatan manusia. Umumnya bencana yang terjadi mengakibatkan kerugian bagi masyarakat seperti banyak nya korban jiwa, kerugian harta benda, kerusakan lingkungan serta hancurnya pembangunan yang telah dicapai sebelumnya. Hal ini tidak dapat dipungkiri karena faktor geografi, geologi (lempeng tektonik) dan demografi Indonesia.Wilayah Sumatera Barat merupakan salah satu daerah yang rawan akan bencana dan sering juga mengalami gempa, seperti gempa yang terjadi pada 30 september 2009 banyak menimbulkan korban jiwa, kerugian harta benda, sarana dan prasarana yang rusak untuk sarana dan prasarana Padang Barat mengalami rusak berat 296, rusak sedang 103, rusak ringan 129(sumber: BPBD Kota Padang). Sebagai bentuk untuk mewujudkan pengurangan risiko 


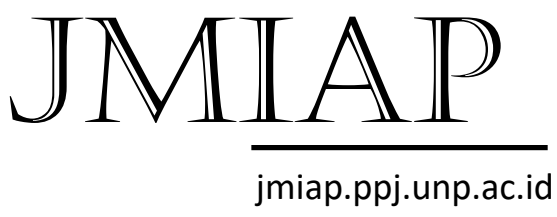

JURNAL ILMU ADMINISTRASI PUBLIK

Email : jianfis.unp@gmail.com

Vol. 2 No. 1 Maret 2019

bencana maka dibentuk Kelurahan Tangguh Bencana yang dibentuk sesuai dengan kriteria yang ditentukan Peraturan Kepala Badan Nasional Penanggulangan Bencana Nomor 1 Tahun 2012 tentang Pedoman Umum Desa/Kelurahan Tangguh Bnencana. Kelurahan Tangguh Bencana adalah desa/kelurahan yang memiliki kemampuan mandiri untuk beradaptasi dan menghadapi potensi ancaman bencana, serta memulihkan diri dengan segera dari dampak bencana yang merugikan. Untuk Kota Padang hanya ada dua kelurahan yang memenuhi kriteria sebagai kelurahan tangguh bencana yaitu Kelurahan Lolong Belanti dan Kelurahan Bungus Selatan ( Sumber : BPBD).

Secara garis besar Desa/Kelurahan Tangguh Bencana memiliki komponen komponen sebagai berikut: 1)legislasi; 2)

perencanaan;3)kelembagaan;4)pendana

an; 5) pengembangan; penyelenggaraan penanggulangan bencana. Berdasarkan 6 komponen Kelurahan Tangguh Bencana yang tertuang pada PERKA BNPB NO 1 Tahun 2012 tentang Pedoman Umum Desa/Kelurahan Tangguh Bencana, Kelurahan Lolong Belanti pada kenyataannya hanya memenuhi 1 dari 6 komponen sehingga program kelurahan tangguh bencana dalam hal ini di Kelurahan Lolong Belanti menjadi tidak optimal.

Masalah yang ditemukan di lapangan terdapat pada perencanaan dimana seharusnya ada penyusunan rencana Penanggulangan Bencana Desa, rencana kontijensi bila menghadapi ancaman tertentu. Namun Kelurahan Lolong Belanti dalam membuat perencanaan rencana kontijensi mengalami kendala. Permasalahan yang terjadi dilapangan yaitu mengenai pemanfaatan baliho yang tidak digunakan untuk bisa diberdayakan menjadi tandu darurat apabila terjadi bencana yang seyogyanya hal ini masuk kedalam rencana kontijensi.

Selain itu masalah yang ditemui di lapangan selanjutnya adalah terdapat pada sumber daya manusia yang kurang, pendanaan yang minim, kurangnya kesadaran masyarakat akan bongkar pasang tenda darurat dan dapur umum, dan kurangnya pemeliharaan pada faslitias tanggap darurat. Dalam melaksanakan suatu program sangat penting memiliki sumber daya manusia dengan jumlah yang besar untuk mendukung tercapainya suatu program. Namun yang terjadi sumber daya manusia masih kurang sehingga program tidak berjalan dengan optimal. Selain itu Pendanaan diperlukan dalam menjalankan suatu program. Program yang telah direncanakan sebelumnya akan terealisasi apabila didukung dengan pendanaan yang cukup namun yang terjadi dilapangan pendanaan masih kurang untuk bisa merealisasikan semua program yang telah di rencanakan sebelumnya dan tidak ada mendapat bantuan dari dana dari BPBD Kota Padang sehingga hal ini juga berdampak kepada pemeliharaan fasilitas tanggap darurat yang masih kurang karena untuk pemeliharaan fasilitas tanggap darurat memerlukan dana besar.

Berdasarkan latar belakang masalah di atas, maka penulis melakukan penelitian di Kelurahan Lolong Belanti Kota Padang mengenai evaluasi program Kelurahan Tangguh Bencana Di Kota Padang (Studi Kasus Di Kelurahan Lolong Belanti Kota Padang). Rumusan masalah yang dikemukakan dalam penelitian ini adalah: 1) Bagaimana pelaksanaan program kelurahan tangguh bencana di Kelurahan Lolong Belanti 


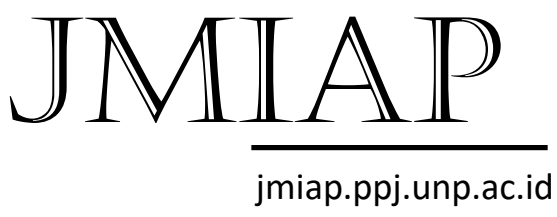

JURNAL ILMU ADMINISTRASI PUBLIK

Email : jianfis.unp@gmail.com

Vol. 2 No. 1 Maret 2019
Kota Padang? dan 2) Apa saja kekuatan, kelemahan, peluang, dan ancaman dalam penerapan program kelurahan tangguh bencana di Kelurahan Lolong Belanti Kota Padang ?

\section{Tinjauan Kepustakaan \\ Manajemen bencana}

Shaluf dalam Bevaola Kusumasari (2014:19) manajemen bencana diartikan sebagai istilah kolektif yang mencakup segala aspek perencanaan untuk merespons bencana, kegiatan-kegiatan pra bencana dan pasca bencana yang mengarah pada manajemen risiko dan konsekuensi bencana. Menurut penulis manajemen bencana merupakan sebuah perencanaan untuk menaggapi bencana,baik sebelum bencana, ketika bencana, dan sesudah bencana. Hal ini selaras dengan pendapat Sadisun (dalam Alhadi, 2014), manajemen bencana merupakan "suatu kegiatan yang terpadu, dinamis dan berkelanjutan, yang dilaksanakan semenjak sebelum kejadian bencana, pada saat atau sesaat setelah bencana hingga pasca bencana."

\section{Tujuan Manajemen Bencana}

Tujuan manajemen bencana secara sederhana tentu saja meminimalisir jatuhnya korban jiwa dan harta benda. Banyak pihak yang kurang menyadari pentingnya mengelola bencana dengan baik. Salah satu faktornya adalah bencana belum tahu kapan dan dimana pastinya akan terjadi walaupun ancamannya bisa diperkirakan.

Djohanpoetro(dalam

Alhadi,2014) megatakan sasaran manajemen bencana yakni : Pertama, Menghindari kerugian masyarakat, ataupun negara dengan cara melakukan kegiatan prabencana). Kedua Mengurangi kerugian masyarakat, ataupun negara yang berkaitan dengan fisik, ekonomi, dan lingkungan. Ketiga, mengurangi kerugian yang dialami oleh masyarakat yang terkena bencana. Keempat, untuk memperbaiki keadaan agar masyarakat dapat memulihkan diri setelah bencana seperti memperbaiki pembangunan yang telah rusak. Kelima mempercepat pemulihan pasca bencana dan mengejar ketertinggalan dengan daerah yang tidak terkena bencana.

\section{Pengurangan Risiko Bencana}

Jonatan Lassa (dalam Ichwan Muis,2018) menjelaskan pengertian Pengurangan Risiko Berbasis Komunitas adalah sebuah pendekatan yang mendorong komunitas untuk mengelola bencana di tingkat loka. Menurut penulis, pengurangan risiko bencana haruslah melibatkan suatu kelompok yang ada dalam masyarakat karena masyarakat itu sendiri yang paling mengenal daerah dan bencana di daerah nya. Hal ini selaras dengan pendapat Barry Adhitya (dalam ichwan Muis, 2018) memberikan alasan pengurangan risiko bencana agar berbasis komunitas (masyarakat). Kelompok siaga bencana/tim relawan PB berbasis komunitas desa/kelurahan perlu menjamin adanya partisipasi dan keterwakilan kepentingan kelompok rentan dan mereka yang kurang beruntung dalam pembangunan (kelompok terpinggirkan) selama proses pengambilan keputusan.

Permasalahan yang terjadi di lapangan adalah minimnya ketersediaan dana, kurangnya sumber daya manusia di Kelurahan Lolong Belanti, rendahnya kapasitas atau pengetahuan stakeholder mengenai pengurangan risiko bencana. Sesuai Perka BNPB No.12 Tahun 2012 tentang Pedoman Umum Desa/ Kelurahan Tangguh Bencana. Sumber Pendanaan untuk kelurahan tangguh bencana seharusnya ada dari BPBD Kota Padang. Namun kenyataan di lapangan 


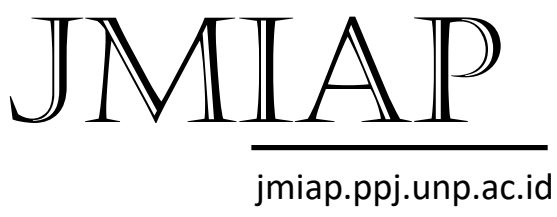

JURNAL ILMU ADMINISTRASI PUBLIK

Email : ¡ianfis.unp@gmail.com

Vol. 2 No. 1 Maret 2019

Kelurahan Lolong Belanti mengalami kendala dalam menjalankan program karena kurangnya ketersediaan dana. Selain itu sumber daya manusia di Kelurahan Lolong Belanti masih kurang saat ini hanya tiga pegawai yang aktif di Kelurahan Lolong Belanti seharusnya jumlah pegawai di Kelurahan Lolong Belanti berjumlah dua belas orang.

\section{Metode Penelitian}

Penelitian ini bersifat kualitatif dengan menggunakan metode deskriptif. Penelitian ini dilakukan di Kelurahan Lolong Belanti Kota Padang. Penentuan informan penelitian dilakukan dengan cara purposive sampling. Jenis data yang digunakan adalah data primer berupa hasil observasi dan wawancara penulis dengan Lurah Lolong Belanti, Anggota LSM Kogami, Ketua KSB Lolong Belanti, Anggota KSB Lolong Belanti, Kepala PK BPBD, Staff PK BPBD, dan Kasubag Umum BPBD. Data sekunder berupa buku Evaluasi Program, materi Pengurangan Resiko Belanti (PRB) Lolong Belanti, buku Hidup Di Atas Patahan Sesar Mentawai, buku Pembelajaran Desa/Nagari Tangguh Bencana di Sumatera Barat, dan jurnal Mitigasi Bencana.

Teknik pengumpulan data yang digunakan dalam penelitian ini adalah wawancara dan studi dokumentasi. Instrument penelitian yang digunakan adalah peneliti sendiri dan alat pengumpul data yang penulis gunakan adalah kamera, HP, dan alat rekaman yang berguna untuk merekam wawancara dengan informan sehingga bisa mempermudah dalam menyusun data. Teknik keabsahan data menggunakan teknik triangulasi sumber. Teknik analisis data dalam penelitian ini dilakukan melalui beberapa tahap, yaitu reduksi data, penyajian data, dan verifikasi data.

\section{Hasil dan Pembahasan}

\section{Evaluasi Program Kelurahan Tangguh Bencana Di Kota Padang ( Studi Kasus Kelurahan Lolong Belanti Kota Padang )}

Berdasarkan indikator evaluasi program menurut stuflebeam dalam (Wakhinuddin S.2009) yaitu CIPP ( Context, Input, Process, Product) maka secara context di Kelurahan Lolong Belanti ini mengarah kepada perumusan tujuan dari program tersebut dan menentukan apa yang dicapai. Tujuan dari program tersebut adalah agar masyarakat mengetahui apa yang harus dilakukan ketika terjadi bencana, masyarakat memiliki pengetahuan mengenai kebencanaan, dan masyarakat sudah terlatih dalam melakukan bongkar pasang tenda hal ini belum semua nya terpenuhi. Secara Context hal ini sudah tepernuhi karena dalam membuat Program di rumuskan tujuan dari program terlebih dahulu.

Secara input di Kelurahan Lolong Belanti ini mengarah kepada rencana kontijensi dan strategi Kelurahan Lolong Belanti untuk mencapai program tersebut. Hal ini belum terpenuhi secara maksimal. Berdasarkan wawancara penulis dengan Bapak Alwis Ucok sebagai Anggota KSB yang dapat disimpulkan bahwa dalam perencaan kontijensi seharusnya ada pemanfaatan baliho agar dapat diberdayakan untuk dijadikan tandu darurat, namun hal ini ditolak oleh BPBD Kota Padang ketika Musrenbang. 
Strategi yang digunakan dalam pencapain program diungkapkan oleh Bapak Abu Bakar Abek Lamno sebagai Ketua KSB yang dapat disimpulkan strategi yang dilakukan seperti koordinasi dengan sesama anggota dan melaporkan ke BPBD Kota Padang, mendatangkan pemateri dan bekerja sama dari berbagai Lembaga yang bergerak di bidang kebencanaan seperti Kogami, melakukan sosialisasi, mengadakan rapat koordinasi dan rapat kerja untuk pencapain target.

Selanjutnya evaluasi process dalam hal ini berkaitan dengan penggunaan fasilitas sesuai yang direncanakan, pendanaan dan sumber daya manusia yang maksimal. Hal ini belum terpenuhi secara menyeluruh. Terbukti pada kelurahan hasil wawancara penulis dengan Abu Bakar Abek Lamno yang dapat disimpulkan yaitu pertama, pada penggunaan fasilitas HT dan RIK sudah terpenuhi hanya saja kurang perawatan. Kedua, selama program dibentuk pelatihan bongkar pasang tenda baru terlaksana satu kali dan tenda yang digunakan untuk pelatihan disewa sedangkan pelatihnya di undang oleh pihak Kelurahan Lolong Belanti. Ketiga, sumber daya manusia di Kelurahan Lolong Belanti yang aktif hanya tiga orang saat ini sehingga belum optimal dalam menjalankan program kelurahan tangguh bencana.

Evaluasi ke empat yaitu product yang mengarah kepada hasil yang telah dicapai dalam pelaksanaan program. Berdasarkan hasil wawancara penulis dengan Bapak Abu Bakar Abek Lamno sebagai Ketua KSB yang dapat disimpulkan bahwa dari empat program yang telah dibentuk sudah tercapai $70 \%$ - 80\%. Program yang belum dilaksanakan ada dua program yaitu program untuk peningkatan kapasitas seluruh stakeholder dan program pelatihan dapur umum. Hal selaras dengan hasil wawancara penulis dengan Ibu Linda sebagai masyarakat Kelurahan Lolong Belanti yang dapat disimpulkan bahwa partisipasi masyarakat masih kurang ketika sosialisasi diadakan yang pada umumnya hanya sekali ikut berpartisipasi dalam sosialisasi mengenai pengurangan risiko bencana.

Temuan diatas tidak sesuai dengan indikator teori evaluasi program yang dikemukakan oleh Stuflebeam yang mengatakan indikator evaluasi program adalah CIPP (context, Input, Process, Product). Seperti dalam proses berjalannya program tidak memiliki dana khusus dari BPBD Kota Padang sebagai kelurahan tangguh bencana, Kelurahan Lolong Belanti yang tidak memiliki fasilitas sendiri seperti tenda darurat dan tidak ada genset di shelter SMA 1 Padang. Selain itu product atau hasil dari program tersebut belum tercapai secara menyeluruh. Masyarakat masih banyak yang tidak memiliki pengetahuan mengenai pengurangan risiko bencana dikarenakan partisipasi masyarakat yang masih rendah.

\section{Analisis SWOT}

Analisis SWOT adalah suatu metode dalam perencanaan stratejik yang dipakai untuk mengidentifikasi 4 faktor utama yang memengaruhi 
kegiatan di dalam organisasi sepanjang masa.SWOT adalah singkatan dari Strengths (Kekuatan), Weaknesses (Kelemahan), Opportunity (Peluang) dan Threats (Ancaman)

a. Kekuatan Program Kelurahan Tangguh Bencana Di Kelurahan Lolong Belanti Kota Padang Strengths (kekuatan) merupakan kondisi dan kemampuan internal yang bersifat positif, yang memungkinkan organisasi memiliki keuntungan dalam mencapai tujuannya. Jika diarahkan kepada program kelurahan tangguh bencana di Kelurahan Lolong Belanti Kota Padang maka kekuatan yang dimaksud adalah sumber daya manusia walaupun masih kurang saat ini. Namun untuk menjalankan program Kelurahan Lolong Belanti memiliki anggota yang cukup banyak dari kelompok siaga bencana.

Berdasarkan temuan dilapangan ada beberapa faktor yang menjadi kekuatan program kelurahan tangguh bencana di Kelurahan Lolong Belanti Kota Padang. Faktor ini dapat menjadi tolak ukur dari kekuatan program tersebut. Faktor pertama adalah sumber daya manusia kelompok siaga bencana yang jumlahnya cukup banyak. Mereka merupakan relawan yang bersedia mengabdi untuk membantu masyarakat. Selain itu hal ini juga didukung dengan kemampuan pegawai Kelurahan Lolong Belanti dalam mengurus urusan administrasi yang diperlukan ke BPBD Kota Padang sehingga program dapat terlaksana. Hal ini dibuktikan dari hasil wawancara penulis dengan Ibu Rini Anggraini sebagai Lurah Lolong Belanti pada hari Rabu, 26 September 2018.

"Saat ini hanya ada tiga pegawai yang aktif di kelurahan, seharusnya di kelurahan ada 12 orang namun mereka sudah pensiun. Jadi tinggal 3 orang saja yang aktif sampai saat ini.kelurahan sendiri juga membantu KSB dalam mengurus urusan administrasi ke BPBD Kota Padang agar program berjalan."

Hal ini selaras dengan hasil wawancara penulis dengan Bapak Abu Bakar Abek Lamno sebagai Ketua KSB Kelurahan Lolong Belanti pada hari Rabu, 26 September 2018 yang mengatakan bahwa :

“ untuk pegawai di Kelurahan saat ini kurang, tapi anggota dari KSB sendiri sudah cukup banyak yaitu 90 orang walaupun seharusnya jumlahnya sebanyak jumlah warga dalam satu RW. Tapi 90 orang ini sudah banyak.

b. Kelemahan Program Kelurahan Tangguh Bencana Di Kelurahan Lolong Belanti Kota Padang

Weakness (Kelemahan) merupakan kekurangan pada kondisi suatu organisasi seperti keuangan, dan fasilitas yang terbatas. Jika diarahkan kepada program kelurahan tangguh bencana di Kelurahan Lolong Belanti Kota Padang maka kelemahan dari program ini adalah minimnya dana/anggaran serta terbatas nya fasilitas dan 
pemeliharaan pada fasilitas kurang. hal ini didukung dengan hasil wawancara penulis dengan Bapak Alwis ucok sebagai anggota KSB Kelurahan Lolong Belanti pada hari Rabu, 26 September 2018.

"Setiap melakukan pelatihan sering menggunakan dana pribadi, tidak ada dana kusus yang diberikan dari BPBD kota Padang yang seharusnya dana itu ada."

Tidak mengalirnya dana dari BPBD kota Padang ke Kelurahan Lolong Belanti berdampak pada saat pelatihan bongkar pasang tenda darurat. Tenda darurat yang seharusnya diberikan dari BPBD kota Padang tidak berjalan dengan semestinya. Hal ini berdasarkan hasil wawancara penulis dengan Ketua KSB Kelurahan Lolong Belanti Abu Bakar Abek Lamno pada hari Senin, 01 Oktober 2018.

"Untuk pelatihan yang dilakukan selama ini kami hanya menyewa tenda dan instruktur untuk beberapa hari ketika pelatihan. Kami tidak memiliki tenda darurat sendiri dan tidak ada diberikan bantuan dari pihak BPBD kota Padang."

Kelurahan Lolong Belanti memiliki 9 buah HT dan 1 buah Rik ( radio Induk) yang diberikan BPBD kota Padang. Alat ini berfungsi ketika terjadi bencana informasi disampaikan melalui RIK (Radio Induk) yang langsung terhubung ke BPBD kota Padang namun untuk pemeliharaan alat masih belum optimal.

Hal ini dibuktikan berdasarkan hasil wawancara penulis dengan Ketua KSB Kelurahan Lolong Belanti pada hari Senin 01 Oktober 2018 bahwasanya:

"Kelurahan Lolong Belanti
memiliki 9 buah HT/walkie
talkie dan 1 buah RIK ( Radio
Induk) dan r untuk
pemeliharaan kurang karena
tidak ada dipakai dan tidak ada
dana diberikan. Karena untuk
pemeliharaan ruga
membutuhkan dana yang
lumayan besar."

c. Peluang Program Kelurahan Tangguh Bencana Di Kelurahan Lolong Belanti Kota Padang Opportunities (peluang) meurpakan segala hal dan situasi yang menguntungkan bagi suatu organisasi. Jika diarahkan kepada program kelurahan tangguh bencana di Kelurahan Lolong Belanti Kota Padang maka peluang dari program ini adalah adanya strategi yang dilakukan oleh kelurahan lolong belanti dalam menjalankan program yang telah dibentuk. Hal ini selaras dengan hasil wawancara penulis dengan Bapak Abu Bakar Abek Lamno sebagai Ketua KSB pada hari Senin, 01 Oktober 2018 bahwasanya :

"Dalam menjalankan program ini kami menggunakan strategi untuk program tersebut seperti selalu koordinasi dengan sesama anggota dan melaporkan ke BPBD Kota Padang sebagai induk 
Organisasi yang di ketehui oleh FKSB Kota Padang. Lalu ada juga mendatangkan pemateri dan bekerja sama dari berbagai Lembaga yang bergerak di bidang kebencanaan,sejauh ini baru dengan kogami. Yang ketiga ada sosialisasi baru berjalan kesekolah sekolah dan rumah warga berdasarkan arahan dan kerjasama dengan BPBD Kota Padang dan FKSB Kota Padang. Yang keempat rutin melaukan evaluasi dengan mengadakan rapat koordinasi dan rapat kerja untuk pencapain target."

Hal selaras dikatakan oleh Bapak Syafri sebagai Ketua RT 04 RW 1 pada hari Minggu, 06 Januari 2019 yang mengatakan bahwa :

"kalau untuk strategi biasanya saya sebagai RT mengumumkan ada sosialiasasi mengenai pengurangan risiko bencana, ada bapak-bapak yang saya minta tolong untuk di ingatkan ke setiap warga ke rumahrumah. "

Kerjasama yang telah dilakukan baik dengan BPBD Kota Padang maupun dengan kogami merupakan salah satu keuntungan bagi kelurahan lolong belanti dikarenakan kerjasama ini dapat membantu secara finansial maupun nonfinansial agar program berjalan.

\section{d. Ancaman Program Kelurahan Tangguh Bencana Di Kelurahan Lolong Belanti Kota Padang}

Threats (ancaman) merupakan faktor lingkungan yang tidak menguntungkan dalam organisasi baik masa sekarang ataupun masa yang akan datang. Jika diarahkan kepada program kelurahan tangguh bencana di Kelurahan Lolong Belanti Kota Padang maka ancaman dari program ini adalah masih rendahnya kapasitas atau pengetahuan masyarakat dalam menyikapi kondisi kota padang yag rawan bencana. Kemampuan masyarakat masih kurang dan belum siap ketika bencana terjadi. Hal ini selaras dengan hasil wawancara penulis dengan Bapak Abu Bakar Abek Lamno sebagai Ketua KSB pada hari Senin, 01 Oktober 2018 bahwasanya:

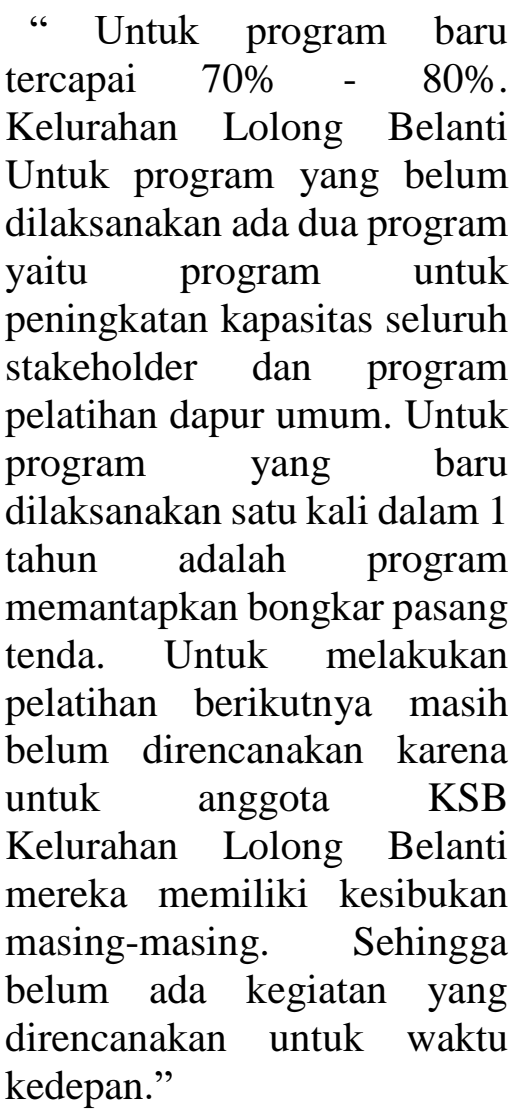

Hal ini selaras dengan hasil wawancara penulis dengan Ibu Yenita sebagai anggota KSB 
Kelurahan Lolong Belanti pada hari Rabu, 26 September 2018, mengatakan:

" untuk program yang baru berjalan secara rutin sekarang baru sosialiasi kalau untuk program lain baru sekali

dilakukan karna anggota KSB banyak memiliki kesibukan sendiri saat ini, tapi kemarin ada rencana mau mengadakan pelatihan bongkar pasang tenda lagi tapi belum jelas tanggal nya. “

Program peningkatan kapasitas seluruh stakeholder yang belum terlaksana merupakan ancaman yang harus diselesaikan. Meskipun program yang telah berjalan mencapai $70 \%$ - 80\% tetap saja hasilnya tidak akan maksimal apabila kapasitas dari stakeholder masih kurang dan program tersebut belum terlaksana. 


\section{Penutup}

Berdasarkan hasil penelitian dan pembahasan yang dilakukan, maka dapat ditarik kesimpulan yaitu :

1. Program yang dilakukan di Kelurahan Lolong Belanti Kota Padang belum berjalan secara optimal.

2. Pengetahuan masyarakat mengenai pengurangan risiko bencana masih rendah

3. Minmnya ketersediaan dana untuk kelurahan tangguh bencana yang seharusnya dana untuk kelurahan tangguh bencana berasal dari APBD

4. Kurangnya sumber daya manusia di Kelurahan Lolong Belanti dimana saat ini pegawai di Kelurahan Lolong Belanti hanya tiga orang yang aktif

5. Kekuatan dari program kelurahan lolong belanti berupa sumber daya manusia kelompok siaga bencana yang jumlahnya cukup banyak. Mereka merupakan relawan yang bersedia mengabdi untuk membantu masyarakat. Selain itu hal ini juga didukung dengan kemampuan pegawai Kelurahan Lolong Belanti dalam mengurus urusan administrasi yang diperlukan ke BPBD Kota Padang sehingga program dapat terlaksana.

6. kelemahan dari program ini adalah minimnya dana/anggaran serta terbatas nya fasilitas dan pemeliharaan pada fasilitas kurang, sedangkan peluang dari program ini adalah adanya strategi yang dilakukan oleh kelurahan lolong belanti dalam menjalankan program yang telah dibentuk.

7. ancaman dari program ini adalah masih rendahnya kapasitas atau pengetahuan masyarakat dalam menyikapi kondisi kota padang yag rawan bencana.

\section{DAFTAR PUSTAKA}

Alhadi, Z. (2014). Kesiapan Jalur Dan Lokasi Evakuasi Publik Menghadapi Resiko Bencana Gempa Dan Tsunami Di Kota Padang (Studi Manajemen Bencana), XIII(1), 35-44.

Bevaola Kusumasari.2014.Manajemen Bencana dan Kapabilitas Pemerintahan Lokal.Yogyakarta:Gava Media

Ichwan Muis, K. A. (2018). Model Kesiapsiagaan Masyarakat dalam Pengurangan Risiko Bencana Tanah Longsor di Desa Tugumukti , Kecamatan Cisarua Kabupaten Bandung Barat Abstrak Community Preparedness Model in Landslide Disaster Risk Reduction in Tugumukti Village , Cisarua Subdistric, 3(4), 19-30.

Perka BNPB 1-2012_Pedoman Umum Desa Kelurahan Tangguh Bencana. (n.d.).

Wakhinuddin.S.2009.Evaluasi

Program.Padang:UNP. Press 
